...........................

Neuronal Activity in Tumor Tissue 


\section{Progress in Experimental Tumor Research}

Vol. 39

Series Editor

Joseph R. Bertino New Brunswick, N.J. 


\section{Neuronal Activity in Tumor Tissue}

Volume Editors

Kurt S. Zänker Witten

Frank Entschladen Witten

16 figures, and 2 tables, 2007 


\section{Progress in Experimental Tumor Research}

Founded 1960 by F. Homburger, Cambridge, Mass.

\author{
Kurt S. Zänker \\ Institute of Immunology \\ University of Witten/Herdecke \\ Stockumer Strasse 10 \\ DE-58448 Witten
}

\section{Frank Entschladen}

Institute of Immunology

University of Witten/Herdecke

Stockumer Strasse 10

DE-58448 Witten

Library of Congress Cataloging-in-Publication Data

Neuronal activity in tumor tissue / volume editors, Kurt S. Zänker, Frank

Entschladen.

p. ; cm. - (Progress in experimental tumor research ; v. 39)

Includes bibliographical references and index.

ISBN 978-3-8055-8246-9 (hard cover : alk. paper)

1. Cancer-Pathophysiology. 2. Neurons. I. Zänker, Kurt S. II.

Entschladen, Frank. III. Series.

[DNLM: 1. Neoplasms-pathology. 2. Neurons. W1 PR668T v. 392007 / QZ 200 N4946 2007]

RC269.N58 2007

$616.99^{\prime} 407-\mathrm{dc} 22$

2006101075

Bibliographic Indices. This publication is listed in bibliographic services, including Current Contents ${ }^{\mathbb{R}}$ and Index Medicus.

Disclaimer. The statements, options and data contained in this publication are solely those of the individual authors and contributors and not of the publisher and the editor(s). The appearance of advertisements in the book is not a warranty, endorsement, or approval of the products or services advertised or of their effectiveness, quality or safety. The publisher and the editor(s) disclaim responsibility for any injury to persons or property resulting from any ideas, methods, instructions or products referred to in the content or advertisements.

Drug Dosage. The authors and the publisher have exerted every effort to ensure that drug selection and dosage set forth in this text are in accord with current recommendations and practice at the time of publication. However, in view of ongoing research, changes in government regulations, and the constant flow of information relating to drug therapy and drug reactions, the reader is urged to check the package insert for each drug for any change in indications and dosage and for added warnings and precautions. This is particularly important when the recommended agent is a new and/or infrequently employed drug.

All rights reserved. No part of this publication may be translated into other languages, reproduced or utilized in any form or by any means electronic or mechanical, including photocopying, recording, microcopying, or by any information storage and retrieval system, without permission in writing from the publisher.

(C) Copyright 2007 by S. Karger AG, P.O. Box, CH-4009 Basel (Switzerland)

www.karger.com

Printed in Switzerland on acid-free paper by Reinhardt Druck, Basel

ISSN 0079-6263

ISBN 978-3-8055-8246-9 


\section{Contents}

VII In Remembrance of Fritz Bender Esq. (1907-1986)

IX Foreword

1 Neuronal Development

Giehl, K.M. (Aarhus)

30 Organization of Peripheral Nerves in Skin, Musculoskeletal System and Viscera

von Düring, M.; Fricke, B. (Bochum)

45 Neurotransmitter Receptor-Mediated Signaling

Pathways as Modulators of Carcinogenesis

Schuller, H.M. (Knoxville, Tenn.)

64 Neuronal Markers in Non-Neuronal Tissues

Hagel, C.; Stavrou, D. (Hamburg)

78 Chemotropic Axon Guidance Molecules in Tumorigenesis Chédotal, A. (Paris)

91 Neoneurogenesis and the Neuro-Neoplastic Synapse Palm, D.; Entschladen, F. (Witten)

99 Neurotransmitter Effects on Tumor Cells and Leukocytes Lang, K.; Bastian, P. (Witten) 
122 Stem Cells and Neurogenesis in Tumors

Varner, J.A. (La Jolla, Calif.)

130 Potential Inhibition of the Neuro-Neoplastic Interactions: The Clue of a GPCR-Targeted Therapy

Muller, J.-M. (Poitiers)

154 The Neuro-Neoplastic Synapse: Does it Exist?

Zänker, K.S. (Witten)

162 Author Index

163 Subject Index 


\section{In Remembrance of Fritz Bender Esq. (1907-1986)}

At this 100th anniversary of Fritz Benders birthday, it is my honorable duty, and soulful wish to reminisce and contemplate the heritage he generously bestowed upon us.

Fritz Bender was born in Heidelberg, the romantic and historical town on the banks of the Neckar. It is here, as well as in many cities strewn across the country, that one can find signs of his work as a unique master of the building trade. City council buildings in Mannheim, and Munich still bear evidence of his skill as plasterer and builder - a sorry consequence of the wide-spread damage caused by the bombings in the Second World War.

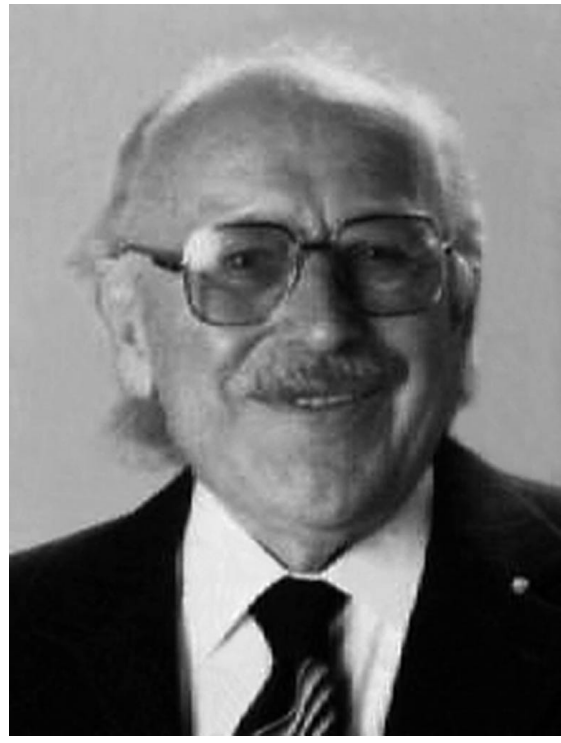

My earliest memories of Mr. Bender are those of his remarkably professional interpretation of a great variety of songs by Robert Schumann, Franz Schubert and Richard Strauß. His voice rang out in a timbre that filled the room, and was but an indication of his greatly facetted talent and character; for he bore and displayed a deep conviction of both symbolism and social aesthetics. He was a 
masterful proponent of the Viennese Classical Period, something deeply rooted and richly lived in his life and work. He put great emphasis on both order and hierarchy, pronouncing a clear segregation of parts, colors and taking preference to simplicity rather than complexity. During the time of our friendship he would often quote Henrik Ibsen from the play 'Bygmester Soleness' (The Master Builder). It is with the words: 'a man could not build so high without paying the penalty of his hubris', that Mr Bender unveiled his wise, and fantastically clear understanding of personal and social responsibility.

On the eve of his death, his personal fight with cancer lead him to bequeath his estate for the endowment of an established trust, known as the Fritz BenderFoundation. Within the genesis of this foundation lies the bold intention to unite the most renowned experts in the field of immunity and the control of cancer, as well as to provide the best resources needed for this battle. It should furthermore be fought by implementing the idea of holism in therapy, and thereby help relieve human suffering caused by maladies of both immunity and cancer. It is the duty of the foundation to ensure and secure the promotion, and attainment of these aims.

Those of us who knew Fritz Bender, and those who receive support from the Fritz Bender-Foundation are deeply beholden to carry forth his social, cultural and scientific legacy both now and beyond the anniversary of his 100th birthday.

Johanna Huber, Hans-Peter Huber, Franz Weigl, Kurt S. Zänker (Board of Directors Fritz Bender Foundation, Munich, Germany). 


\section{Foreword}

In his book The Structure of Scientific Revolution, Kuhn [1] presented the idea that science does not evolve gradually towards truth, but instead undergoes periodic revolutions, which he called paradigm shifts. According to Kuhn, scientists do not use their puzzle-solving abilities to change old theories but take them for granted and use them as tools, often resulting in their enterprise itself becoming puzzle-solving. When the normal scientist is confronted with evidence that the current paradigm may not be correct, he/she tends to ignore it, blaming the mistake on experimental error instead of critically investigating the anomaly. The non-continuous model of scientific progress is exemplified by Judah Folkman's isolation of a tumor factor responsible for angiogenesis and, later on, for the development of a new class of drugs, the angiogenesis inhibitors. This was a fundamental correction of past errors that cytotoxic drugs were the only valid paradigm with no development of alternative theories. A similar change of paradigm is on the horizon in the 21st century, when scientists are trying to understand the interconnecting plasticity of tumor and neuronal cell signaling.

In adult organisms, the peripheral nervous system is highly dynamic and is able to regenerate. It can also respond and adapt to environmental influences not only by its main function - forwarding electrical membrane potentials as well as releasing of neurotransmitters and hormones - but by the nerve cells themselves which are able to adjust through morphological and metabolic changes. The wiring and organization of the peripheral nervous system and some of its key features and potential interactions with tumor cells forming a neuro-neoplastic synapsis are explained by Giehl (Aarhus) and von Düring and Fricke (Bochum) in the first two chapters of this book. 
There are three modes in which neurotrophic factors and neurotransmitters play a role in tumor and neurotrophic cells:

(1) The tumor cells are able to secrete substances which act in an autocrine or paracrine loop when the acceptor cells express the appropriate receptors; here, we speak about an autocrine neuro-neoplastic synapsis. Functional responses provided by this type of autocrine activity are highlighted in the chapters by Chedotal (Paris) who deals with the neurotrophic factors and Lang and Bastian (Witten) who address the neurotransmitters.

(2) The tumor cells secrete neurotrophic factors and neurotransmitters, but are not necessarily sensitive to them. However, these secreted molecules can attract nerve cells to grow into the tumor tissue and, thus, adapt an innervation over time by the inducible expression of appropriate receptors. Palm and Entschladen (Witten) discuss this possibility in detail and Hagel and Stavrou (Hamburg) embarks on the presence of neuronal marker structures within a solid tumor tissue and highlights the corresponding prognostic value. Varner (San Diego, Calif., USA) shows parallels of the innervation process - also called neo-neurogenesis - with the process of neo-angiogenesis, which was first discovered 30 years ago.

(3) The tumor cells express receptors for neurotrophic factors and neurotransmitters and respond to the release of these substances by producing neurogenic phenotypes with cell functions such as increase/decrease of proliferation, apoptosis, and migration; the latter, when circumventing the immunosurveillance, leads to invasion and formation of metastases. Schuller (Knoxville, Tenn., USA) gives strong evidence in her contribution that carcinogenesis mostly the initial step - is modulated by neurotransmitters such as acetylcholine and norepinephrine.

Last, but not least, and considering the hypotheses formulated and facts presented in this book, Muller (Poitiers) discusses some pharmacological approaches to inhibit the interaction between the nervous system and tumor; Zänker (Witten) puts forward the question whether there is substantiated evidence to coin the term 'neuro-neoplastic synapsis' and, by understanding the mode of action, whether it is a novel target structure for an antitumor therapy analogous to the inhibition of angiogenesis.

This book was only made possible because leading authorities from a number of relevant disciplines contributed to this most fascinating field at the frontier of cancer network research with special reference to the description of the 'brain within the tumor' [2]. The distinguished authors guarantee that this book will offer the reader sufficient insight into the cancer research problems of tomorrow; hopefully, the presentation of a whole lot of fascinating details may stimulate scientists in cancer research to keep a keen eye on this particular field. 
We are grateful to the Karger Publishing House, Basel, Switzerland, and to J.R. Bertino, the Editor-in-Chief of this long-standing and well-recognized series Progress in Experimental Tumor Research for publishing this volume. We are thus able to render novel results in basic sciences of cancer research understandable to our clinicians, friends and politicians. If we cannot find the means of doing so, we researchers engaged in basic sciences may face the danger of losing support from the scientific community.

Frank Entschladen, $P h D$

Kurt S. Zänker, $M D, D V M$

\section{References}

1 Kuhn TS: The Structure of Scientific Revolution, ed 1. Chicago, University of Chicago Press, 1962.

2 Chedotal A, Kerjan G, Moreau-Fauvarque C: The brain within the tumor: new roles for axon guidance molecules in cancers. Cell Death Differ 2005;12:1044-1056. 
